Jurnal Konstruksi Hukum | ISSN: XXXX | E-ISSN: XXXX

Vol. 1, No. 2, Oktober 2020, Hal. 300-304| Available online at https://www.ejournal.warmadewa.ac.id/index.php/jukonhum

DOI: https://doi.org/10.22225/jkh.1.2.2566.300-304

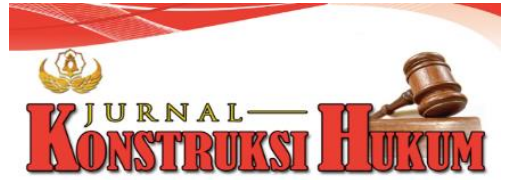

\title{
Tanggung Jawab Notaris terhadap Pembuatan Akta Otentik yang Didasari Surat Palsu
}

\author{
I Made Dwi Sanjaya, Ida Ayu Putu Widiati, Ni Ketut Sri Astiti \\ Fakultas Hukum Universitas Warmadewa, Denpasar-Bali, Indonesia
}

\begin{abstract}
Abstrak
Penelitian ini bertujuan untuk mengetahui faktor-faktor yang menyebabkan terjadinya pembuatan akta otentik yang didasari surat palsu oleh Notaris dan mengetahui akibat hukum bagi Notaris berkaitan dengan pembuatan Akta otentik yang didasari surat palsu. Penelitian menggunakan metode penelitian Hukum Normatif. Hasil penelitian menunjukan bahwa akta otentik yang didasari surat palsu merupakan suatu akta yang dibuat secara tidak sah dihadapan pejabat umum yang berwenang, sehingga nampak seperti aslinya. Kemudian, faktor penyebab pembuatan Akta otentik yang didasari surat palsu adalah ketidaktahuan notaris bahwa surat yang dibuat itu palsu. Pelaku tidak memiliki itikad baik dalam membuat akta otentik tersebut. Oleh karena itu, konsekuensi kepada Notaris yang terbukti telah bekerja sama dalam pembuatan Akta otentik yang didasari surat palsu, maka akta yang dibuat oleh Notaris tersebut akan memiliki pembuktian akta dibawah tangan dan akan batal demi hukum, serta notaris tersebut dapat diancam pidana dengan berdasarkan ketentuan pasal 263 dan 266 Kitab Undang- Undang Hukum Pidana.
\end{abstract}

Kata Kunci: Tanggung Jawab Notaris; Akta Otentik; Surat Palsu

\begin{abstract}
This study aims to determine the factors that lead to the making of authentic deeds based on fake letters by notaries and to find out the legal consequences for notaries related to making authentic deeds based on fake letters. This research uses the normative law research method. The results showed that an authentic deed based on a fake letter was a deed made illegally in front of the authorized public official, so that it looks like the original. Then, the factor that caused the making of an authentic deed based on a fake letter was the notary's ignorance that the letter made was fake. The perpetrator did not have good faith in making the authentic deed. Therefore, as a consequence to a Notary who is proven to have cooperated in making an authentic Deed based on a false letter, the deed made by the Notary will have proof of the deed under hand and will be null and void, and the notary may be subject to criminal penalties under the provisions of the article 263 and 266 Criminal Code.
\end{abstract}

Keywords: Responsibility of the Notary; Deed of Authentic; Fake Letter

\section{PENDAHULUAN}

Negara Indonesia merupakan Negara Hukum dimana seluruh kekuasaan tunduk kepada hukum, tentu saja seluruh tindakan yang dilakukan oleh masyarakat Indoneia di atur oleh hukum, semua tindakan masyarakat Indonesia diikat oleh hukum, salah satu bentuk pengikatan hukum dalam bidang hukum perdata yaitu salah satunya tertuang dalam bentuk perjanjian perjanjian ada dua yaitu perjanjian dalam bentuk yaitu perjanjian lisan dan perjanjian tertulis, perjanjian tertulis tertuang dalam dua bentuk yaitu akta otentik dan perjanjian dibawah tangan.

Perjanjian lisan memiliki pembuktian yang lemah dan perjanjian tertulis memliki kekuatan pembuktian yang kuat maka dari itu masyarakat lebih memilih untuk membuat atau mengikatkan diri mereka masing-masing dalam perjanjian tertulis terutama dalam bentuk akta otentik karena akta otentik memiliki kekuatan pembuktian yang sempurna. Akta otentik merupakan perjajian yang dilakukan dihadapan pejabat umum, pejabat umum disini merupakan Notaris, Notaris berwenang membuat akta.

Beberapa penelitian mengenai pemalsuan akta telah banyak dilakukan sebelumnya, seperti Hendra (2012); Muhammad, Widowaty, \& Raharjo (2019); Santyaningtyas \& Zubaidi (2020); Tedjosaputro (2020); Utami, Ali, \& Din (2016). Dalam proses pembuatan akta otentik ada saja akta yang dibuat didasari oleh Surat Palsu dimana didalam akta tersebut masih terdapat keterangan palsu yang mana 
merugikan salah satu pihak dalam perjanjian terebut sehingga sering kali Notaris dituntut atas kerugian tersebut, namun hal ini tidak dapat dibenarkan apabila notaris dituntut untuk bertanggungjawab dalam pembuatan akta otentik yang berisikan keterangan palsu atau menuduh notaris mencatumkan keterangan palsu dalam akta tersebut mengingat Notaris hanyalah mencantumkan apa yang telah diterangkan oleh para pihak dan dalam membuat akta, Notaris tidak boleh menaruh rasa curiga atas apa yang telah disodorkan kepadanya.

Namun apabila Notaris dalam menjalankan tugas jabatannya terbukti sengaja melakukan suatu pelanggaran maka Notaris tersebut wajib bertanggung jawab sesuai dengan perbuatan apa yang telah dilakukannya, jika Notaris tersebut dalam pembuatan akta tersebut memang terbukti telah bekerja sama untuk melakukan kecurangan dalam pembuatan akta otentik tersebut atau bekerja sama mebuat suatu keterangan palsu/ keterangan yang tidak sebenarnya maka Notaris tersebut juga dapat dipidana. Oleh karena itu, penelitian baru ini bertujuan untuk menganalisis factor-faktor terjadinya Pembuatan akta otentik yang didasari surat palsu oleh Notaris dan mengetahui akibat hukum bagi Notaris berkaitan dengan pembuatan akta otentik yang didasari surat palsu.

\section{METODE PENELITIAN}

Penelitian ini menggunakan metode penelitian hukum Normatif dengan pendekatan pendekatan perundang-undangan. Sumber data yang digunakan dalam penelitian adalah dokumentasi berupa perundang-undangan yang sifatnya mengikat (acuan utama) dan sumber lain seperti bukubuku/literatur-literatur yang berhubungan dengan permasalahan yang dikaji. Teknik pengumpulan data yang digunakan adalah studi kepustakaan dan studi dokumen yang dilakukan dengan cara data dibaca terlebih dahulu, kemudian dicatat dan dianalisis dengan mensistematiskan terhadap bahan-bahan hukum yang diperoleh.

\section{HASIL DAN PEMBAHASAN}

\section{Faktor-Faktor yang Menyebabkan Terjadinya Pembuatan Akta Otentik yang Didasari Surat Palsu oleh Notaris}

Akta otentik merupakan akta yang dibuat oleh kedua belah pihak dihadapan pejabat umum yang berwenang, pejabat umum yang berwenang tersebut yaitu Notaris. Akta otentik dikatakan akta yang memiliki kekuatan pembuktian yang sempurna dikarenakan akta tersebut bukan hanya dibuat berdasarkan peraturan perundang-undangan yang ada namun dikarenakan dibuat dihadapan Notaris/pejabat umum yang berwenang (Notodisoerjo, 2010).

Akta otentik yang dibuat dihadapan Notaris berpedoman pada peraturan perundang- uandangan yang mana syarat sahnya suatu perjanjian ditentukan dalam pasal 1320 KUHP (kitab uandang-undang Hukum perdata) yang mana menentukan bahwa:

1. Terdapatnya kesepakatan antara kedua belah pihak

2. Cakapnya kedua belah pihak dalam membuat suatu perjanjian

3. Terdapatnya suatu hal tertentu untuk diperjanjikan

4. Perjanjian yang dibuat tidak bertentangan dengan kausa yang halal/ peraturan perundangundangan yang ada.

Akta yang dibuat dihadapan Notaris merupakan akta yang memiliki pembuktian yang sempurna dan juga akta tersebut dapat menghindari suatu sengketa. Namun, dalam prakteknya seringkali timbul sengketa dimana terdapat akta Notaris yang didasari oleh surat palsu yang menimbulkan suatu kerugian bagi pihak yang berkepentingan. Dalam pembuatan akta otentik yang didasari surat palsu merupakan tindakan pidana, surat palsu berarti perbuatan meniru dimana keterangan yang terdapat dalam surat tersebut tidak asli, tidak tulen, tidak sah, tiruan dan tidak jujur yang tampak seperti aslinya.

Maka akta otentik yang didasari surat palsu adalah akta yang dibuat dihadapan pejabat umum yang berwenang yaitu Notaris yang dalam pembuatan akta tersebut didasari surat palsu yang didalamnya berisi keterangan yang tidak asli, tidak sah, tidak tulen yang dibuat seolah-olah seperti aslinya.

Kewenangan Notaris tampak dalam pasal 1 angka 1 undang-undang Nomor 2tahun 2014 tentang jabatan Notaris yaitu membuat akta otentik yang mana Notaris tidak boleh membuat akta untuk dirinya sendiri keluarga sedarah, istri, suami Dalam pembuatan akta otentik (Tobing, 1996:5). Notaris tidak boleh menaruh rasa curiga terhadap keterangan apapun yang telah disodorkan oleh kedua belah pihak 
dalam pembuatan akta tersebut, sehingga sering kali terdapat akta yang tidak sah atau akta otentik yang dalam pembuatannya telah didasari oleh surat palsu.

Adapun faktor-faktor yang menyebabkan pembuatan akta otentik yang didasari surat palsu oleh Notaris di nyatakan dalam wawancara pada tanggal 26 Januari 2019 dengan Bapak Dr. I Nyoman Alit Puspadma, SH.,M.Kn. selaku Notaris/ Pejabat Pembuat Akta Tanah yang berkedudukan di Kabupaten Badung bahwa faktor-faktor yang mempengarui pembuatan Akta Otentik yang didasari surat palsu:

1. ketidaktahuan Notaris bahwa surat itu palsu, karena Notaris dalam membuat akta tidak boleh menaruh rasa curiga dan harus menyakini keterangan apapun yang disodorkan dihadapannya, maka dari itu Notaris berpotensi tidak mengetahui kebenaran yang sesungguhnya atas keterangan yang dihadapkan dihadapannya.

2. Si pembuat akta tersebut tidak memiliki itikad baik, dimana dengan sengaja salah satu pihak atau kedua belah pihak membuat surat palsu atau memberikan keterangan palsu untuk disodorkan kepada Notaris yang dimana surat/ keterangan tersebut menjadi dasardalam pembuatan akta otentik.

3. Notaris mengabaikan prinsip-prinsip kehati-hatian, Notaris mengabaikan prinsip kehatihatian disini maksudnya adalah Notaris tidak melakukan pengenalan terhadap kedua belah pihak berdasarkan identitas yang disodorkan di hadapan Notaris, dan memeriksa secara cermat serta teliti dokumen-dokumen baik subjek maupun obyek yang nantinya akan dimasukkan dalam akta otentik yang dibuat oleh Notaris.

4. Adanya persekongkolan antara Notaris dan kedua belah pihak dalam pembuatan akta tersebut yang mana Notaris terebut bekerjasama atau ikut mencantumkan keterangan yang tidak benar dalam akta tersebut.

Jadi yang menjadi faktor-faktor pembuatan Akta otentik yang didasari oleh surat palsu adalah faktor yang berasal dari diri si pembuat dan bisa saja faktor yang berasal dari kelalaian Notaris itu sendiri.

\section{Akibat Hukum bagi Notaris yang Berkaitan dengan Pembuatan Akta Otentik yang Didasari Surat Palsu}

Dalam pembuatan akta otentik yang didasari surat palsu merupakan perbutan melawan hukum. Menurut, Chazawi \& Ferdian (2014:12), perbuatan melawan hukum tersebut dalam konteks pidana perbuatan yang dilarang oleh Undang-undang dengan diancam pidana yang mana unsur-unsurnya, yaitu

1. Unsur objektif, unsur objektif merupakan unsur yang berasal dari luar diri manusia yaitu dapat berupa:

a. Tindakan yangmana tidak tunduk dan dilarang oleh Undang-undang seperti pemalsuan surat, sumpah palsu, penggelapan.

b. Akibat terentu yang dilarang seperti pembunuhan, penganiyayaan.

c. Keadaan yang khusus yang dilarang oleh Undang-undang seperti penghasutan, melanggar kesusilaan.

2. Unsur subjektif, unsur subjektf merupakan unsur yang bersal dari diri manusia itu sendiri.

Berkaitan dengan unsur-unsur pidana terebut pasal 263 KUHP mengenai pemalsuan terhadap akta otentik Notaris tidak dapat di pidana dengan pasal tertentu. Akan tetatapi Notaris tersebut dapat dikenakan sanksi pidana berdasarkan ketentuan pasal 246 KUHP karena dalam pasal ini menentuntukan bahwa sanksi tersebut diperberat karena objek dari pemalsuan ini yaitu akta otentik yang pada dasarnya sebenarnya memiliki pembuktian yang sempurna, yang mana dalam isidari akta tersebut berisi keterangan kebenaran yang sesungguhnya. Apabila seseorang dengan sengaja menyuruh/ memerintahkan Notaris dalam pembuatan akta otentik tersebut mencantumkan keterangan palsu maka dapat dikenakan sanksi pidana yaitu pasal 266 KUHP.

Dalam Undang- Undang Nomor 2 tahun 2014 Tentang Jabatan Notaris berkaitan dengan pemalsuan akta otentik tidak ada pengaturan yang khusus mengatur tentang itu, maka jika ada Notaris yang di peralahkan dalam akta otentik yang menimbulkan kerugian terhadap salah satu pihak yang mana terdapat keterangan palsu dalam akta tersebut maka hal ini akan menimbulkan kerancuan apakah Notaris akan memang secara sengaja maupun kehilafan dari Notaris tersebut. Berkaitan dengan hal ini Notaris juga dapat dihukum dan tidak kebal hukum.

Notaris dapat saja di hukum pidana apabila terbukti dalam pengadilan bahwa Notaris tersebut secara sengaja bersama-sama dengan para pihak atau salah satu pihak melakukan sesuatu yang dapat 
merugikan. Berkaitan dengan kewenangan Notaris dalam Membuat akta otentik yang memenuhi unsurunsur pidana maka Notaris diperlukan kehadirannya tindakan pidana tersebut seperti:

1. Ditetukan dalam pasal 55 KUHP yang mana menentukan bahwa bilamana Notaris turut serta melakukan atau bersama-sama melakukan tindak pidana melanggar Undang-Undang Jabatan Notaris bersama dengan pihak lain.

2. Ditentukan dalam pasal 231 KUHP dimana Notaris dengan sengaja mengesahkan seperti KTP yang pada sahnya Notaris tersebut mengetahui bahwa KTP tersebut tidak asli.

3. Pasal 263 KUHP menentukan bahwa jika Notaris dengan sengaja yang dimana kedudukan Notaris dalam akta tersebut tidak memiliki kepentingan telah dengan sengaja melakukan kerjasama dengan salah satu pihak untuk membuat akta tersebut seolah-olah seperti asli padahal akta tersebut palsu sehingga merugikan salah satu pihak yang berkepentingan.

4. Pasal 266 KUHP dimana notaris tidak berhati-hati dalam mencantumkan keterangan yang dihadapkan kepadanya oleh salah satu pihak hal ini disebut telah menaruh suatu keterangan palsu dalam akta tersebut.

Dalam Undang-Undang Nomor 2 tahun 2014 tentang Jabatan Notaris ditentukan ada dua jenis sanksi perdata terhadap akta otentik yang merugikan yaitu Akta otenik tersbut akan berubah menjadi akta dibawah tangan dan Akta tersebut dapat batal demi hukum. Jadi Notaris juga dapat dipidana apabila Notaris terbukti ikut serta dalam pelanggaran tersebut dan dikenakan sanksi sesuai dengan yang telah ditentukan.

\section{SIMPULAN DAN SARAN Simpulan}

Akta otentik yang didasari surat palsu merupakan akta yang dibuat dihadapan Notaris yang mana pada dasarnya akta tersebut didasari oleh surat palsu yaitu berisikan keterangan palsu, tidak asli, tidak sah, yang mana factor-faktor yang mempengaruhi pembuatan akta otentik yang didasari oleh surat palsu adalah faktor yang mana berasal dari kesengajaan yang dari salah satu pihak dimana salah satu pihak memang memiliki itikad tidak baik dan faktor yang berasal dari kelalaian Notaris yang tidak memperhatikan prinsip kehati-hatian dalam pembuatan akta tersebut dan kerjasama dari Notaris tersebut.

Kemudian, akibat hukum bagi Notaris dalam pembuatan akta Otentik yang didasari surat palsu adalah sesuai dengan ketentuan pasal 84 Undang-Undang Nomor 2 Tahun 2014 tentang Jabatan Notaris maka akta yang dibuat oleh Notaris tersebut berubah menjadi akta dibawah tangan dan dapat batal demi hukum. Apabila Notaris tersebut terbukti dalam pengadilan telah melanggar ketentuan yang berlaku maka Notaris tersebut dapat dipidana dan dapat dihukum sesuai dengan ketntuan pidana yang telah dilanggar.

\section{Saran}

Melalui penelitian ini diharapkan kepada pemerintah agar membentuk peraturan kusus yang mengatur tentang sanksi bagi Notaris yang dengan sengaja telah membuat suatu akta otentik yang didasari surat palsu. Selain itu, diharapkan kepada Notaris dalam membuat akta agar berhati-hati dan memperhatikan prinsip kehati-hatian dan bertindak cermat dalam menjalankan tugas profesinya, serta mempelajari lebih dalam tugas profesinya dan kewenangan serta kode etik yang dimiliki Notaris agar tidak terjadi kesalahan dalam pembuatan akta otentik tersebut.

\section{Daftar Pustaka}

Chazawi, A., \& Ferdian, A. (2014). Tindak Pidana Pemalsuan. Jakarta: PT. Raja Grafindo Persada.

Hendra, R. (2012). Tanggungjawab Notaris terhadap Akta Otentik yang Penghadapnya Mempergunakan Identitas Palsu di Kota Pekanbaru. Jurnal Ilmu Hukum, 3(1).

Muhammad, F. N., Widowaty, Y., \& Raharjo, T. (2019). Penerapan Sanksi Pidana Terhadap Pemalsuan Akta Otentik yang Dilakukan oleh Notaris. Media of Law and Sharia, 1(1), 1-13.

Notodisoerjo, R. S. (1982). Hukum Notariat di Indonesia Suatu Penjelasan. Jakarta: Rajawali Pers.

Santyaningtyas, A. C., \& Zubaidi, R. (2020). Role of Land Deed Officials in Legal Satisfaction Guarantee for Complete Systematic Land Registration. Jurnal Notariil, 5(1), 49-57.

Tedjosaputro, L. (2020). Authentic Deed of Notary That Carries Criminal Charges. In International Conference on Law, Economics and Health (ICLEH 2020) Authentic (Vol. 140, pp. 508-510). Atlantis Press. 
Jurnal Konstruksi Hukum

Vol. 1, No. 2, 2020

Tobing, G. H. . L. (1996). Peraturan Jabatan Notaris (3rd ed.). Jakarta: Erlangga.

Utami, A. R., Ali, D., \& Din, M. (2016). Pertanggungjawaban Pidana Pejabat Notaris terhadap Tindak Pidana Pemalsuan Akta Autentik. Jurnal Ilmu Hukum, 4(2), 13-17.

Undang-UndangNomor 2 Tahun 2014 Tentang Jabatan Notaris Tentang Perubahan Atas Undang-Undang Nomor 30 Tahun 2004 Tentang Jabatan Notaris 